\title{
Prevalence of Low Back Pain and Associated Factors in Older Adults: Amazonia Brazilian Community Study
}

\author{
Ingred Merllin Batista de Souza ${ }^{1, * \mathbb{D}}$, Lilian Regiani Merini ${ }^{2}$, Luiz Armando Vidal Ramos ${ }^{1}$, \\ Anice de Campos Pássaro ${ }^{1}$, João Italo Dias França ${ }^{3}$ and Amélia Pasqual Marques ${ }^{1}$ \\ 1 Department of Physical Therapy, Speech-Language Pathology, and Audiology and Occupational Therapy, \\ Faculty of Medicine at University of São Paulo, Cipotânea Street, Vila Universitária, 51, \\ São Paulo 05360-000, SP, Brazil; luiz.armando@usp.br (L.A.V.R.); anicepassaro@usp.br (A.d.C.P.); \\ pasqual@usp.br (A.P.M.) \\ 2 Department of Faculty of Physical Education and Physical Therapy at Federal University of Amazonas, \\ Manaus, Jauary Marinho Avenue, Coroado, Manaus 69067-005, AM, Brazil; merinililian@hotmail.com \\ 3 Dante Pazzanese of Cardiolgy Institute, Avenue Dr Dante Pazzanese, 500, Vila Mariana 69077-000, SP, Brazil; \\ jitalo@outlook.com \\ * Correspondence: ingredmerllin@usp.br
}

check for updates

Citation: de Souza, I.M.B.; Merini, L.R.; Ramos, L.A.V.; Pássaro, A.d.C.; França, J.I.D.; Marques, A.P. Prevalence of Low Back Pain and Associated Factors in Older Adults: Amazonia Brazilian Community Study. Healthcare 2021, 9, 539 https: / / doi.org/10.3390/ healthcare 9050539

\section{Academic Editors:}

Daniela Figueiredo, Oscar Ribeiro, Andrea Tittarelli and Christopher R. Cogle

Received: 18 January 2021

Accepted: 14 April 2021

Published: 5 May 2021

Publisher's Note: MDPI stays neutral with regard to jurisdictional claims in published maps and institutional affiliations.

Copyright: (c) 2021 by the authors. Licensee MDPI, Basel, Switzerland. This article is an open access article distributed under the terms and conditions of the Creative Commons Attribution (CC BY) license (https:// creativecommons.org/licenses/by/ $4.0 /)$.
Abstract: To investigate the prevalence of low back pain (LBP) and associated factors in the older adult Amazonia Brazilian community, a cross-sectional study was conducted to evaluate 700 participants that were $\geq 60$ years old. Pain intensity and functional disability were assessed using the Numerical Pain Scale and the Roland Morris Questionnaire, respectively, and their sociodemographic, clinical, and behavior variables were collected, i.e., age, sex, education level, socioeconomic level, anthropometric measurements, physical activity, health perception, and emotional state. The punctual prevalence rates of LBP were $42.4 \%$ (95\% CI: 38.2-46.6\%), and for the last 365 days, these prevalence rates were $93.7 \%$ (95\% CI: 91.3-95.6\%), the mean pain and functional disability scores were $6.17 \pm 2.13$ and $11.30 \pm 6.07$, and the moderate-to-severe disability was $39.7 \%$. Pain and functional disability were associated with sex, chronic diseases, body mass index (BMI), physical activity level, health perception, and emotional level. In conclusion, the prevalence of LBP was high (for both punctual and the last 365 days), but the variables associated with being female, fewer years of schooling, sedentary behavior, diseases related to diet and the cardiovascular system, and impaired emotional levels had a higher level LBP, even though they considered themselves in good health. These findings can aid with coordinated efforts from government and health professionals to help manage and promote the prevention of LBP by considering the older adult population's needs in the state of Amazonas.

Keywords: prevalence; low back pain; older adults; pain; functional disability

\section{Introduction}

Low back pain (LBP) is the leading global cause of years lost due to disability and its burden is growing with the aging of the population [1]. LBP is an extremely common symptom that is experienced by people of all ages [2-4]. In 2015, the one-time global prevalence of activity-limiting LBP was 7.3\%, which implies that 540 million people were affected by it [1]. LBP is defined by the location of the pain, typically between the lower margins of the ribs and the gluteal folds [2]. It is commonly accompanied by pain in one or both legs, and some people with LBP have associated neurological symptoms in the lower limbs [5]. The symptoms are often related to aging [6,7], and although it is identified as a common health problem, its prevalence is little known in the older adult population $[8,9]$.

A systematic review [10], with data from the international literature on the prevalence of LBP in the older adult population (in developing or developed countries), indicates a high prevalence of LBP among older people, ranging from 21.7 to $75 \%$. In the first nationwide meta-analysis that investigated the prevalence of LBP in older people in Brazil, 
Leopoldino et al. [11] provided moderate-quality evidence that the punctual prevalence of LBP in older Brazilians was 25.0\% (95\% CI: 18.0-32.0\%). From a national perspective, this finding supports the notion that LBP is one of the most relevant health conditions in old age. Due to its impact on disability, the older adult population experience greater dependence, vulnerability, and lower quality of life [12].

In addition, knowing the sociodemographic and behavioral profiles, work habits, and general health factors associated with LBP in this group is essential for the development of public policies that are aimed at controlling the problem, which would be based on preventive measures and/or therapeutic interventions [13]. Therefore, this study aimed to investigate the prevalence of LBP and associated factors in the older adult population in an Amazonia Brazilian community.

\section{Materials and Methods}

\subsection{Study Design}

This cross-sectional study followed the Strengthening the Reporting of Observational Studies in Epidemiology (STROBE) [14] guidelines.

\subsection{Study Population}

The inclusion criteria were older people that were $\geq 60$ years old, both sexes, living in the urban area of Manaus, Amazonas. The participants were asked, "Did you feel pain in the lumbar spine (lumbar region) in the past 3 months, regardless of time or duration?" A lumbar region image was presented along with verbal questioning to obtain more specific pain location information, and to allow for the questionnaires to be answered more independently. This study considered the nonspecific LBP definition according to Maher et al. [15]. The exclusion criteria were people who underwent a surgical procedure on the spine [16], used a wheelchair, used assistive walking devices, and had cognitive impairment. Interviews were carried out in places with a large flow of people of all age groups, and the participants were informed about all stages of the study and that their participation would be voluntary; they could leave the study at any time without causing any harm and with our responsibility of maintaining data confidentiality. The study was approved by the Research Ethics Committee of the Faculty of Medicine of the University of São Paulo, São Paulo, Brazil (protocol number: 189/16), and it is part of a multicenter study entitled "Low back pain prevalence in older Brazilian adults from different populations".

\subsection{Sample Size}

In order to calculate the sample size, an estimate of LBP prevalence was used based on a systematic review, which assessed the worldwide prevalence of LBP. The parameters used were as follows: total older adult population in the city of Manaus, Amazonas $=108,100$ [17], adjusted mean prevalence of LBP in the last month $=23.2 \%(p=0.232)$ [3], accuracy of $4 \%$ ( $p=0.04), 95 \%$ confidence interval $(z=1.96)$, and allowing for a sample loss of $20 \%$ due to refusal and incomplete questionnaires. The total sample size of the study was 513 individuals of the older adult population presented in each of the cities included in the multicenter study. In addition, it was not necessary to perform a finite correction of the population because the calculated sample was less than $5 \%$ of the older adult population [18].

\subsection{Evaluation}

\subsubsection{LBP Prevalence: Punctual and for the Last 365 Days}

For this study, an episode of LBP was considered as any pain between the last rib and the bottom of the gluteal folds lasting more than $24 \mathrm{~h}$, preceded by 30 days without pain [2]; an episode of nonspecific LBP, which was defined as LBP that was not attributable to a recognizable or previously known specific pathology, was also accepted [15]. Prevalence was measured in terms of punctual pain (at the time of the interview) and from the last 365 days (any occurrence in the last year). To enable the exact identification of the lumbar 
region, the interviewees received an illustrative figure of the human body that specified the lower back with dotted lines. The frequency, duration, and radiating pain were also investigated; we assessed whether the LBP was sufficient to limit daily activities for more than one day and whether there was radiating pain to the lower limbs.

\subsubsection{Sociodemographic and Clinical Variables}

Sociodemographic characteristics (sex, age, marital status, and self-reported skin color), education level, occupational activity (that was performed for most of their lives), emotional level, health perception, self-reported diseases, alcohol consumption, and smoking status were evaluated. Anthropometric variables [19] (weight and height) were used to calculate the stratified body mass index (BMI).

The physical activity level was assessed using the International Physical Activity Questionnaire (IPAQ short version) [20], which classifies physical activity levels according to the frequency, duration, and intensity of the individual's activity in their free time, travels, and domestic and occupational activities.

\subsubsection{Pain Assessment}

Pain intensity was assessed using the Numerical Pain Scale (NPS), which is an 11-point scale ranging from 0 to 10, with zero points indicating the absence of pain and 10 points indicating unbearable pain. The individuals were asked about the presence of pain, specifically located in the lower back. The NPS is widely used in studies of this nature to subjectively quantify pain intensity [21].

\subsubsection{Functional Disability}

Functional disability was assessed using the Roland Morris Questionnaire (RMQ), which is an instrument that was translated and adapted for the Brazilian population [22] and is widely used in research and clinical practice to assess the disability associated with LBP. It consists of 24 questions that are related to the normal activities of daily living. Participants were asked to identify the items in the questionnaire that they considered challenging to perform on that day because of LBP. The questionnaire score ranges from 0 to 24 points; higher scores indicate a more significant functional disability. Scores above 14 points correspond to severe functional disability [21].

\subsubsection{Statistical Analysis}

Qualitative variables were presented as absolute and relative frequencies, and quantitative variables were presented as means and standard deviations or medians and quartile intervals, if indicated. Thereby, the absolute and relative frequencies of the sociodemographic, clinical, and behavioral variables of all participants were calculated, including the pain intensity (mean, median, and standard deviation), the level of functional disability (mean, median, and standard deviation), the prevalence of punctual LBP and for the last 365 days, along with the respective $95 \%$ confidence intervals (CIs).

Fisher's exact test [23] was used to verify the associations between the qualitative variables. To check the relationship between the quantitative variables and the two groups, Student's $t$-test or the Mann-Whitney test was used. Analysis of variance (assumption of normality) or the Kruskal-Wallis test (nonparametric) was used when there were more than two groups [24]. The prevalence ratio (PR) of unbearable pain and functional disability was calculated. The robust Poisson model $[25,26]$ was used to calculate the adjusted PR, adjusting for age and sex [27], with explicative variables that have a $p$-value $<0.15$. The data were analyzed using IBM Corporation., 2010 SPSS version 19 Armonk, NY and R Core version 3.5.1 (R Foundation for Statistical Computing, Vienna, Austria). The significance level adopted was $5 \%$. 


\section{Results}

We recruited 700 older adults and amongst them, 76.4\% (95\% CI: 76.4-82.5\%) had LBP according to the study definition. Figure 1 shows a flowchart of the prevalence (punctual and for the last 365 days) of LBP in this study. The estimated mean for the punctual prevalence of LBP was 42.4\% (95\% CI: 38.2-46.6\%), while the estimated mean for the prevalence in the last 365 days was 93.7\% (95\% CI: 91.3-95.6\%). For those who reported having LBP at the time of the interview, the mean pain score was 6.17 points (SD: 2.13 ).

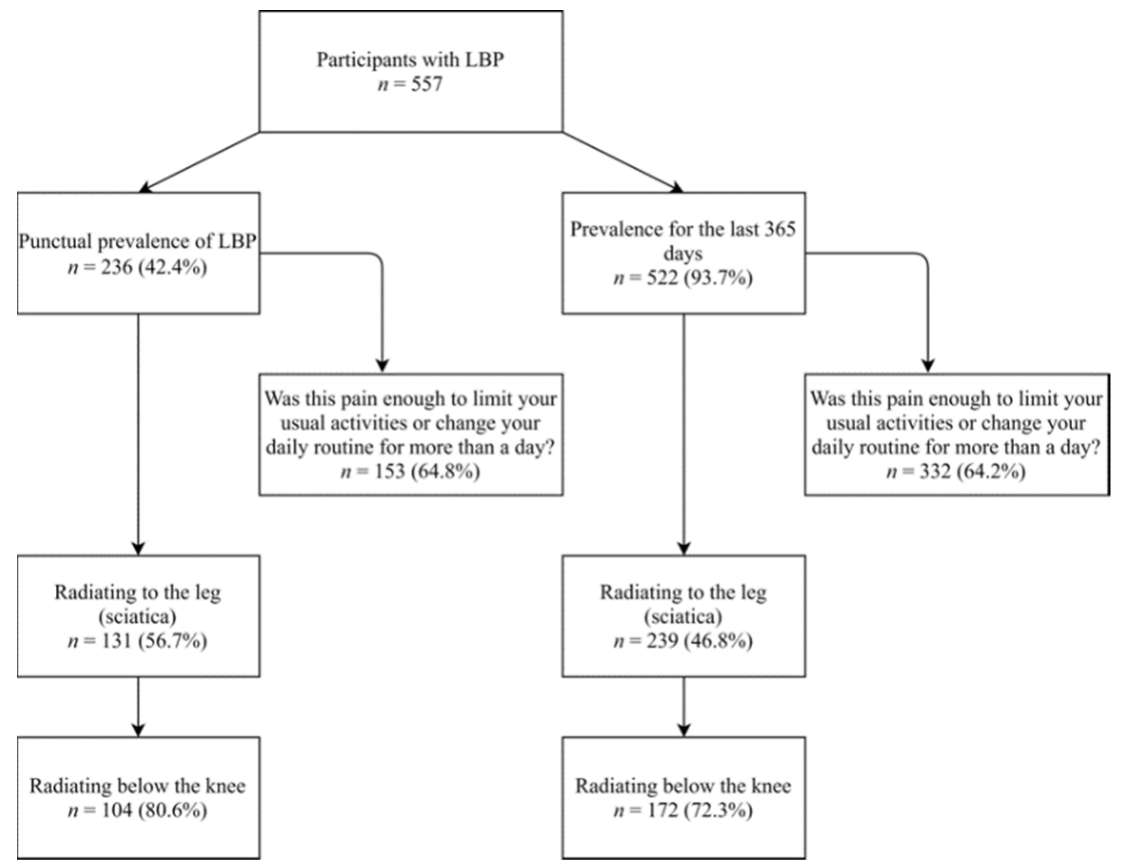

Figure 1. Flowchart of punctual prevalence and prevalence for the last 365 days.

Regarding the mean for functional disability, the score was 11.3 points (SD: 6.07), however, scores $\geq 14$ points, which is considered moderate to severe disability, were observed in $39.7 \%$ of participants. In the RMQ, the most frequent answers were: "I change position frequently to try and get my back comfortable (84.2\%); I avoid heavy jobs around the house because of my back (74.9\%); because of my back, I try not to bend or kneel down (73.1\%); because of my back, I go upstairs more slowly than usual (62.1\%); I walk more slowly than usual because of my back (57.1\%); because of my back, I use a handrail to get upstairs (55.5\%); I only stand for short periods because of my back (53.3\%); because of my back, I lie down to rest more often (50.6\%)".

Table 1 shows sociodemographic characteristics and the association with pain intensity and functional disability in the participants with the presence of LBP. There were 546 (79.6\%) female participants, and the mean age of the participants was 67.07 years (SD: 5.98 years). The associations found with sex were for pain $(p=0.039)$ and functional disability $(p \leq 0.001)$; the number of years of schooling was only associated with pain $(p \leq 0.001)$.

The participant's clinical and behavioral characteristics and their associations with pain intensity and functional disability are shown in Table 2 . Around $44.7 \%$ had obesity $\left(\mathrm{BMI}>27 \mathrm{~kg} / \mathrm{m}^{2}\right)$ and were classified as having sedentary $(36 \%)$ or active $(34.7 \%)$ lifestyles. When asked whether physical health or emotional problems interfered with normal physical and social activities (family, friends, or groups), 48.3\% of the older adults reported that they "in no way" let these factors influence their lives. The perception of health was considered "regular" (46.7\%), and the most commonly reported diseases were diabetes mellitus (43.9\%) and arterial hypertension (43.9\%). 


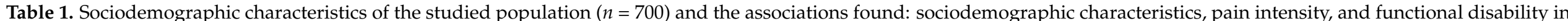
older people with low back pain $(n=557)$.

\begin{tabular}{|c|c|c|c|c|c|c|c|c|c|}
\hline Variable & $\begin{array}{c}\text { Participants } \\
n=700(\%)\end{array}$ & $\begin{array}{c}\text { Pain Median } \\
\quad(557)\end{array}$ & $\begin{array}{c}\text { First } \\
\text { Quartile } \\
\text { Interval }\end{array}$ & $\begin{array}{c}\text { Third } \\
\text { Quartile } \\
\text { Interval }\end{array}$ & $p$-Value & $\begin{array}{c}\text { Functional } \\
\text { Disability } \\
\text { Median (557) }\end{array}$ & $\begin{array}{c}\text { First } \\
\text { Quartile } \\
\text { Interval }\end{array}$ & $\begin{array}{c}\text { Third } \\
\text { Quartile } \\
\text { Interval }\end{array}$ & $p$-Value \\
\hline \multicolumn{10}{|l|}{ Sex } \\
\hline Female & $546(78)$ & 6 & 5.00 & 8.00 & $0.039^{1}$ & 12 & 7.00 & 17.00 & \multirow{2}{*}{$<0.001$} \\
\hline Male & $154(22)$ & 6 & 5.00 & 7.00 & & 9 & 4.50 & 12.00 & \\
\hline \multicolumn{10}{|l|}{ Age group } \\
\hline 60 to 70 years old & $526(75.1)$ & 6 & 5.00 & 8.00 & \multirow{2}{*}{$0.651^{2}$} & 11 & 6.00 & 16.00 & \multirow{2}{*}{$0.220^{2}$} \\
\hline$>80$ years old & $28(4)$ & 6 & 5.00 & 7.00 & & 15 & 7.00 & 19.00 & \\
\hline \multicolumn{10}{|c|}{ Skin color (self-reported) } \\
\hline Yellow & $27(3.9)$ & 7 & 5.50 & 8.00 & \multirow[t]{5}{*}{$0.866^{2}$} & 11 & 6.00 & 16.00 & \multirow{5}{*}{$0.790^{2}$} \\
\hline White & $196(28)$ & 6 & 5.00 & 8.00 & & 11 & 7.00 & 17.00 & \\
\hline Indigenous & $18(2.6)$ & 6 & 5.00 & 7.00 & & 12 & 5.00 & 15.00 & \\
\hline Brown & $387(55.3)$ & 6 & 5.00 & 8.00 & & 11.5 & 7.00 & 16.00 & \\
\hline Black & $72(10.3)$ & 6 & 5.00 & 8.00 & & 10.5 & 4.50 & 16.00 & \\
\hline \multicolumn{10}{|l|}{ Marital status } \\
\hline Married & $338(48.3)$ & 6 & 5.00 & 8.00 & \multirow[t]{4}{*}{$0.357^{2}$} & 11 & 5.50 & 16.00 & \multirow{4}{*}{$0.483^{2}$} \\
\hline Divorced & $65(9.3)$ & 6 & 4.50 & 7.00 & & 10 & 5.00 & 14.50 & \\
\hline Single & $118(16.9)$ & 6 & 5.00 & 8.00 & & 11 & 7.00 & 17.00 & \\
\hline Widower & $179(25.6)$ & 6 & 5.00 & 7.00 & & 11 & 8.00 & 16.00 & \\
\hline \multicolumn{10}{|l|}{ Individual income * } \\
\hline Without income & $85(12.1)$ & 6 & 5.00 & 8.00 & \multirow{6}{*}{$0.096^{2}$} & 12.5 & 5.50 & 18.00 & \multirow{6}{*}{$0.168^{2}$} \\
\hline Class A & $2(0.3)$ & 7.5 & 7.00 & 8.00 & & 17.5 & 12.00 & 23.00 & \\
\hline Class B & $6(0.9)$ & 6 & 6.00 & 7.00 & & 9 & 0.00 & 19.00 & \\
\hline Class C & $46(6.6)$ & 5 & 4.00 & 7.00 & & 8 & 4.50 & 13.50 & \\
\hline Class D & $123(17.6)$ & 6 & 5.0 & 7.00 & & 10 & 7.00 & 15.00 & \\
\hline Class E & $438(62.6)$ & 6 & 5.00 & 8.00 & & 11 & 6.00 & 17.00 & \\
\hline
\end{tabular}


Table 1. Cont

\begin{tabular}{|c|c|c|c|c|c|c|c|c|c|}
\hline Variable & $\begin{array}{c}\text { Participants } \\
n=700(\%)\end{array}$ & $\begin{array}{c}\text { Pain Median } \\
(557)\end{array}$ & $\begin{array}{c}\text { First } \\
\text { Quartile } \\
\text { Interval }\end{array}$ & $\begin{array}{c}\text { Third } \\
\text { Quartile } \\
\text { Interval }\end{array}$ & $p$-Value & $\begin{array}{c}\text { Functional } \\
\text { Disability } \\
\text { Median (557) }\end{array}$ & $\begin{array}{c}\text { First } \\
\text { Quartile } \\
\text { Interval }\end{array}$ & $\begin{array}{c}\text { Third } \\
\text { Quartile } \\
\text { Interval }\end{array}$ & $p$-Value \\
\hline \multicolumn{10}{|l|}{ Education (years) } \\
\hline Did not study & $3(0.4)$ & 8 & 7.00 & 8.50 & $<0.001^{2}$ & 17 & 10.50 & 18.50 & \multirow{5}{*}{$0.064^{2}$} \\
\hline 1 to 4 years & $219(31.3)$ & 6 & 5.00 & 8.00 & & 12 & 7.00 & 17.00 & \\
\hline 5 to 8 years & 135 (19.3) & 7 & 5.00 & 9.00 & & 13 & 7.00 & 18.00 & \\
\hline 9 to 11 years & $76(10.9)$ & 5 & 4.00 & 7.00 & & 10 & 5.00 & 15.00 & \\
\hline >11 years & $267(38.1)$ & 6 & 5.00 & 7.50 & & 10 & 5.00 & 15.00 & \\
\hline Previous occupation ${ }^{* *}$ & \multicolumn{9}{|c|}{$0.536^{2}$} \\
\hline $\begin{array}{c}\text { Armed forces, police, and military } \\
\text { Firefighters }\end{array}$ & $2(0.3)$ & 4 & 2.00 & 6.00 & & 6 & 3.00 & 9.00 & \multirow{8}{*}{$0.066^{2}$} \\
\hline Science and arts professionals & $75(10.7)$ & 6 & 5.00 & 7.00 & & 8 & 4.00 & 14.00 & \\
\hline $\begin{array}{l}\text { Agricultural, forestry, hunting, and } \\
\text { fishing workers }\end{array}$ & $69(9.9)$ & 6 & 6.00 & 7.50 & & 13.5 & 7.00 & 17.50 & \\
\hline $\begin{array}{l}\text { Industrial goods and service } \\
\text { production workers } 1\end{array}$ & $77(11)$ & 6 & 5.00 & 7.50 & & 10 & 7.50 & 18.00 & \\
\hline $\begin{array}{l}\text { Industrial goods and service } \\
\text { production workers } 2\end{array}$ & $29(4.1)$ & 6 & 5.00 & 8.00 & & 11 & 4.50 & 16.00 & \\
\hline Administrative service workers & $65(9.3)$ & 6 & 5.00 & 6.00 & & 12 & 5.00 & 18.00 & \\
\hline $\begin{array}{l}\text { Service workers and salespeople in } \\
\text { shops and markets }\end{array}$ & $352(50.3)$ & 6 & 5.00 & 7.00 & & 11 & 7.50 & 15.00 & \\
\hline Secondary school technicians & $29(4.1)$ & 6 & 5.00 & 8.00 & & 12 & 7.00 & 16.00 & \\
\hline \multicolumn{10}{|l|}{ Current Occupation } \\
\hline Do not work & $634(90.6)$ & - & & - & - & - & - & & - \\
\hline Work & $66(9.4)$ & - & & - & - & - & - & & - \\
\hline
\end{tabular}

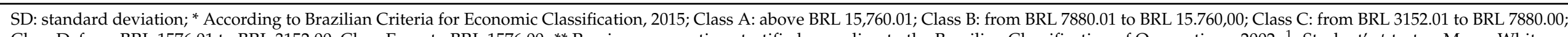

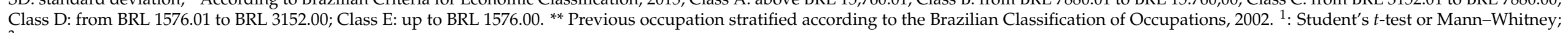

2: ANOVA or Kruskal-Wallis test. 


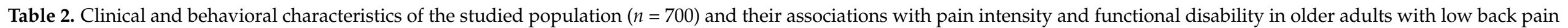
$(n=557)$.

\begin{tabular}{|c|c|c|c|c|c|c|c|c|c|}
\hline Variable & $\begin{array}{c}\text { Participants } \\
n=700(\%)\end{array}$ & $\begin{array}{c}\text { Pain Median } \\
(557)\end{array}$ & $\begin{array}{c}\text { First } \\
\text { Quartile } \\
\text { Interval }\end{array}$ & $\begin{array}{c}\text { Third } \\
\text { Quartile } \\
\text { Interval }\end{array}$ & $p$-Value & $\begin{array}{c}\text { Functional } \\
\text { Disability } \\
\text { Median (557) }\end{array}$ & $\begin{array}{c}\text { First } \\
\text { Quartile } \\
\text { Interval }\end{array}$ & $\begin{array}{c}\text { Third } \\
\text { Quartile } \\
\text { Interval }\end{array}$ & $p$-Value \\
\hline \multicolumn{10}{|c|}{$\operatorname{BMI}\left(\mathrm{kg} / \mathrm{m}^{2}\right) *$} \\
\hline$<22$ : underweight & $77(11)$ & 6 & 5.00 & 8.00 & $0.048^{2}$ & 13 & 7.00 & 18.00 & \multirow{3}{*}{$<0.001^{2}$} \\
\hline 22-27: normal weight & $310(44.3)$ & 6 & 5.00 & 7.00 & & 10 & 5.00 & 15.00 & \\
\hline$>27$ : obesity & $313(44.7)$ & 6 & 5.00 & 8.00 & & 12 & 7.00 & 17.00 & \\
\hline \multicolumn{10}{|c|}{ Physical activity level (IPAQ) } \\
\hline Very active & $55(7.9)$ & 6 & 4.00 & 7.00 & \multirow{3}{*}{$0.085^{2}$} & 9 & 3.50 & 12.00 & \multirow{3}{*}{$<0.001^{2}$} \\
\hline Insufficiently active & $150(21.4)$ & 6 & 5.00 & 7.00 & & 10 & 7.00 & 16.00 & \\
\hline Sedentary & $252(36)$ & 6 & 5.00 & 8.00 & & 14 & 7.00 & 18.00 & \\
\hline \multicolumn{10}{|l|}{ Smoking } \\
\hline Nonsmoker & $447(63.9)$ & 6 & 5.00 & 8.00 & \multirow[t]{3}{*}{$0.245^{2}$} & 12 & 7.00 & 17.00 & \multirow{3}{*}{$0.658^{2}$} \\
\hline Ex-smoker & $235(33.6)$ & 6 & 5.00 & 8.00 & & 10 & 6.00 & 15.00 & \\
\hline Smoker & $18(2.6)$ & 6 & 6.00 & 9.00 & & 9 & 6.00 & 16.00 & \\
\hline \multicolumn{10}{|c|}{ Alcohol consumption } \\
\hline Do not consume & $594(84.9)$ & 6 & 5.00 & 8.00 & \multirow{5}{*}{$0.464^{2}$} & 11 & 7.00 & 17.00 & \multirow{5}{*}{$0.139^{2}$} \\
\hline Once a month or less & $61(8.7)$ & 6 & 5.00 & 7.00 & & 12.5 & 5.50 & 15.00 & \\
\hline Twice to four times/month & $35(5.0)$ & 6 & 4.00 & 7.50 & & 9 & 4.00 & 12.5 & \\
\hline Twice to three times/week & $8(1.1)$ & 5.5 & 5.00 & 6.00 & & 7.5 & 3.00 & 9.00 & \\
\hline Four or more times/week & $2(0.3)$ & 4.5 & 4.00 & 5.00 & & 12.5 & 8.00 & 17.00 & \\
\hline \multicolumn{10}{|l|}{ Emotional Level ** } \\
\hline No way & $338(48.3)$ & 6 & 5.00 & 7.50 & $0.007^{2}$ & 8.5 & 4.00 & 14.00 & \multirow{5}{*}{$<0.001^{2}$} \\
\hline Lightly & $172(24.6)$ & 6 & 5.00 & 8.00 & & 14 & 8.00 & 18.00 & \\
\hline Moderately & $123(17.6)$ & 6 & 5.00 & 7.00 & & 12 & 8.00 & 17.00 & \\
\hline Considerable & $42(6)$ & 7 & 5.00 & 9.00 & & 15 & 12.00 & 18.00 & \\
\hline Extremely & $25(3.6)$ & 8 & 6.00 & 10.00 & & 14 & 11.00 & 19.00 & \\
\hline
\end{tabular}


Table 2. Cont.

\begin{tabular}{|c|c|c|c|c|c|c|c|c|c|}
\hline Variable & $\begin{array}{c}\text { Participants } \\
n=700(\%)\end{array}$ & $\begin{array}{c}\text { Pain Median } \\
(557)\end{array}$ & $\begin{array}{c}\text { First } \\
\text { Quartile } \\
\text { Interval }\end{array}$ & $\begin{array}{c}\text { Third } \\
\text { Quartile } \\
\text { Interval }\end{array}$ & $p$-Value & $\begin{array}{c}\text { Functional } \\
\text { Disability } \\
\text { Median (557) }\end{array}$ & $\begin{array}{c}\text { First } \\
\text { Quartile } \\
\text { Interval }\end{array}$ & $\begin{array}{c}\text { Third } \\
\text { Quartile } \\
\text { Interval }\end{array}$ & $p$-Value \\
\hline \multicolumn{10}{|l|}{ Health perception } \\
\hline Bad & $87(12.4)$ & 8 & 5.50 & 10.00 & \multirow[t]{5}{*}{$<0.001^{2}$} & 16 & 11.00 & 20.00 & \multirow{5}{*}{$<0.001^{2}$} \\
\hline Regular & $327(46.7)$ & 6 & 5.00 & 8.00 & & 11 & 7.00 & 16.00 & \\
\hline Good & $233(33.3)$ & 6 & 4.00 & 7.00 & & 10 & 4.00 & 15.00 & \\
\hline Very good & $43(6.1)$ & 6 & 5.00 & 6.00 & & 8.5 & 4.00 & 11.00 & \\
\hline Excellent & $10(1.4)$ & 4.5 & 3.00 & 10.00 & & 4.5 & 1.00 & 10.00 & \\
\hline \multicolumn{10}{|l|}{ Disease (self-reported) ${ }^{* * *}$} \\
\hline \multirow{2}{*}{ Diabetes mellitus } & \multirow{2}{*}{$160(28.8)$} & Absent 6 & 5.00 & 8.00 & \multirow[t]{2}{*}{$0.077^{1}$} & Absent 11 & 6.00 & 16.00 & \multirow[b]{2}{*}{$0.032^{1}$} \\
\hline & & Present 7 & 5.00 & 8.00 & & Present 12 & 7.00 & 17.00 & \\
\hline \multirow{2}{*}{ Dyslipidemia } & \multirow{2}{*}{$17(3.1)$} & Absent 6 & 5.00 & 8.00 & \multirow[t]{2}{*}{$0.255^{1}$} & Absent 11 & 6.00 & 16.00 & \multirow{2}{*}{$<0.001^{1}$} \\
\hline & & Present 6 & 4.00 & 6.00 & & Present 16 & 14.00 & 20.00 & \\
\hline \multirow{2}{*}{ Arterial hypertension } & \multirow{2}{*}{$244(43.9)$} & Absent 6 & 5.00 & 8.00 & \multirow[t]{2}{*}{$0.521^{1}$} & Absent 10 & 5.00 & 16.00 & \multirow{2}{*}{$0.051^{1}$} \\
\hline & & Present 6 & 5.00 & 8.00 & & Present 12 & 7.00 & 17.00 & \\
\hline Rheumatoid arthritis & $86(9)$ & & & & & & & & \\
\hline Osteoarthritis & 99 (11) & & & & & & & & \\
\hline Other diseases & $62(6)$ & & & & & & & & \\
\hline Did not report & $169(17)$ & & & & & & & & \\
\hline
\end{tabular}

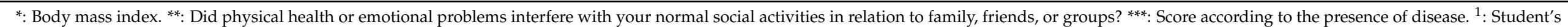
$t$-test or Mann-Whitney test; ${ }^{2}$ : ANOVA or Kruskal-Wallis test. 
For both pain and functional disability, there were associations with BMI $(p=0.048$ and $p<0.001$, respectively), health perception ( $p \leq 0.001$ and $p<0.001$, respectively), and emotional level ( $p=0.007$ and $p<0.001$, respectively). Functional disability was associated with self-reported hypertension $(p=0.051)$, diabetes mellitus $(p=0.032)$, dyslipidemia $(p<0.001)$, and physical activity level $(p<0.001)$.

We observed that only the diabetes mellitus (DM) variable was statistically significant, where the PR was 1.24 ( $p$-value $=0.0274)$. In other words, older participants with diabetes mellitus had a 1.24 times higher prevalence of having unbearable pain than participants without the disease (Table 3).

Table 3. Poisson distribution and the association with unbearable pain.

\begin{tabular}{|c|c|c|c|c|c|c|}
\hline \multirow[b]{2}{*}{ Variable } & \multirow[b]{2}{*}{ Coefficient } & \multirow[b]{2}{*}{ SE } & \multirow[b]{2}{*}{ PR } & \multicolumn{2}{|c|}{$95 \%$ CI } & \multirow[b]{2}{*}{$p$-Value } \\
\hline & & & & $\begin{array}{l}\text { Lower } \\
\text { Limit }\end{array}$ & $\begin{array}{l}\text { Higher } \\
\text { Limit }\end{array}$ & \\
\hline Intercept & -0.5739 & 0.6291 & & & & \\
\hline Age & -0.0088 & 0.0083 & 0.9912 & 0.9753 & 10.074 & 0.2889 \\
\hline Sex (male) & -0.2628 & 0.1460 & 0.7689 & 0.5776 & 10.236 & 0.0718 \\
\hline BMI & 0.0128 & 0.0076 & 10.129 & 0.9978 & 10.282 & 0.0943 \\
\hline DLP & -0.5783 & 0.4443 & 0.5609 & 0.2348 & 13.398 & 0.193 \\
\hline $\mathrm{DM}$ & 0.2163 & 0.0981 & 12.415 & 10.244 & 15.046 & 0.0274 \\
\hline Education (5 to 8 years) & 0.1408 & 0.1216 & 11.512 & 0.907 & 1.461 & 0.247 \\
\hline Education ( 9 or more years) & -0.1543 & 0.1141 & 0.857 & 0.6853 & 10.718 & 0.1761 \\
\hline
\end{tabular}

BMI: body mass index; DLP: dyslipidemia; DM: diabetes mellitus.

The male sex variable was statistically significant. The PR was 0.66 ( $p$-value 0.012 ), i.e., they were $34 \%$ less likely to have a functional disability. The dyslipidemia variable was statistically significant and the PR was 2.14 ( $p$-value $<0.001$ ), i.e., they were 2.14 times more likely to have a functional disability. The variable sedentary behavior was statistically significant and the PR was 1.56 ( $p$-value < 0.001), i.e., being sedentary was 1.56 times more likely to be associated with a functional disability (Table 4).

Table 4. Poisson distribution and association with functional disability.

\begin{tabular}{ccccccc}
\hline & & & & \multicolumn{2}{c}{$95 \%$ CI } & \\
\cline { 5 - 6 } Variable & Coefficient & SE & PR & $\begin{array}{c}\text { Lower } \\
\text { Limit }\end{array}$ & $\begin{array}{c}\text { Higher } \\
\text { Limit }\end{array}$ & $p$-Value \\
& & & & & & \\
\hline Intercept & -19.871 & 0.6224 & & & & 0.0014 \\
Age & 0.0054 & 0.0082 & 10.054 & 0.9895 & 10.216 & 0.5064 \\
Sex (male) & -0.4032 & 0.1607 & 0.6682 & 0.4877 & 0.9156 & 0.0121 \\
BMI & 0.0146 & 0.0080 & 10.147 & 0.9989 & 10.308 & 0.0684 \\
Arterial hypertension & 0.1067 & 0.1019 & 11.126 & 0.9111 & 13.585 & 0.2952 \\
DLP & 0.7629 & 0.1537 & 21.445 & 15.868 & 28.982 & $<0.0001$ \\
DM & 0.1357 & 0.1030 & 11.453 & 0.9359 & 14.014 & 0.1877 \\
Education (5 to 8 years) & 0.2146 & 0.1341 & 12.394 & 0.9529 & 16.119 & 0.1095 \\
Education (9 or more years) & -0.0093 & 0.1238 & 0.9907 & 0.7773 & 12.626 & 0.9399 \\
Physical activity level & 0.4471 & 0.1039 & 15.638 & 12.757 & 19.171 & $<0.0001$ \\
(sedentary) & & & & & & \\
\hline
\end{tabular}

BMI: body mass index; DLP: dyslipidemia; DM: diabetes mellitus.

\section{Discussion}

The prevalence of LBP was higher in this community of older Amazonia Brazilian adults than in the studies carried out in other Brazilian cities, such as Tabocal in Bahia (18.3 to $23.4 \%$ ) [28] and São Paulo in São Paulo (25.4\%) [29]. A high punctual prevalence of LBP $(42.4 \%)$ and prevalence for the last 365 days $(93.7 \%)$ were found.

Regarding spine health, previous studies conducted in Brazil identified that spinal musculoskeletal problems were the second most commonly reported health condition in 
2003 and 2008 [30]. In addition, they were also the third most common cause of early retirement due to disability in 2007, creating a high demand for health services amongst older adults [27,30]. Although the prevalence and burden associated with LBP in terms of disability increase with age [31], information about LBP in the older population is minimal, and most studies exclude these individuals.

In this study, the pain score was considered moderate and the functional disability was classified as moderate-to-severe in $39.7 \%$ of the participants. This level of functional disability serves as an alert because it shows that it is essential to understand the aspects of the daily living activities that have been reported as difficult to perform because of pain. Dionne et al. [32] carried out a systematic review of all epidemiological studies that examined LBP prevalence by age and identified that people of different ages define disabling pain differently. The authors state that although older adults experience a decrease in non-disabling back pain, their results support the hypothesis that older people less frequently experience or report benign or mild back pain, but they experience a higher prevalence of episodes that are severe or disabling. Furthermore, this is also supported by the findings of Stewart et al. [33], who reported that the frequency of onset of pain that interferes with daily life continues to increase with age.

In fact, in our study, the Amazonas elderly population who lived either in hospital care or in community centers were in the places the interviews were conducted. In other words, our sample differs from the data to others Brazilian cities [11] since the characteristics of the places where data was collected may have contributed to the higher prevalence of low back pain.

Given the social, cultural, and economical fundamental differences between developed and developing countries, it is reasonable to argue that the antecedents and consequences of LBP are not homogeneous. For instance, extreme poverty, infectious epidemic disease, type of occupational activities, family structure, responsibilities, social expectations, geography, and availability and access to health care can have different impacts on the perception and in the reporting of back pain in different contexts [33].

Pain and functional disability were associated with the variables sex, BMI, physical activity level, health perception, and emotional level in our study. These findings are similar to the findings of the study carried out by Hartvigsen et al. [5], which reported that LBP is a complex condition with several contributors to the occurrence of pain; they reported that social, biological, physical, and comorbid factors influence the mechanisms of pain processing and often hamper pain management itself.

Regarding the sex distribution, previous studies showed that women have higher pain prevalence than men $[29,34]$. This is corroborated by our findings: women were more likely to have LBP compared to men. However, women live longer than men and, thus, are exposed to risk factors for longer; they live with more comorbidities and experience the chronicity of clinical conditions [35]. Murtagh and Hubert [36] described the higher prevalence of disabilities related to health problems in women compared to older men. In a systematic review, the authors suggested that multiple biopsychosocial mechanisms (such as genetics, sex hormones, and pain control) may interact and contribute to the phenomenon [37].

Some studies [38,39] indicate that a high BMI is a risk factor for LBP, corroborating this study's findings. In line with this evidence, Shiri et al. [40] conducted a systematic review that aimed to investigate the relationship between body weight and LBP, and claimed that overweight and obesity are potentially modifiable risk factors for preventing LBP. In contrast, Stewart et al. [33] and Weiner et al. [41] did not find an association between obesity and disability; however, they evaluated obesity differently compared to our study, where they used waist circumference. In this regard, it is important to highlight the association between these two conditions in this population; although they differ from other studies related to disability due to LBP, these contradictions do not yet provide a conclusive statement. 
The prevalence of physical inactivity increases with the aging process [42] and is high amongst the older population worldwide (46.5\%) [43]. This is also considered one of the most significant public health problems in modern society [44]. In our study, $36 \%$ of the older people were considered sedentary and there was a continuous association between LBP and functional disability. Furthermore, the regression model suggested that the ones who considered themselves sedentary had a 1.65 times higher chance of having a functional disability; this was similar to that found in Canada, wherein sedentary individuals were $33 \%$ more likely to have a functional disability than the active ones [45]. Physical activity was an important predictor of functional capacity in the participants with LBP. The more active an older person is, respecting their biological individuality, the better they will live, with improvements not only in musculoskeletal conditions but also in the quality of life and independence [46,47].

Psychological factors influence the disabilities associated with musculoskeletal pain amongst older people $[32,39]$. The findings of our study regarding the question about LBP and its influence in emotional aspects ("Did physical health or emotional problems interfere with your normal social activities in relation to family, friends, or groups?") showed an association between pain and functional disability ( $p=0.007$ and $p<0.001$, respectively). However, the psychological aspects of its influence seemed to vary depending on age and the cultural environment. In addition, psychosocial and emotional problems influence both the chronicity of LBP and pain in general. These conditions are important issues for general practitioners and other professionals dealing with multimorbidity [48]. Moreover, the biopsychosocial consequences of chronic pain emphasize the importance of measuring and investigating its prevalence to plan actions for its control and treatment [29]. To properly address the sociodemographic and psychosocial LBP-related factors within older people, we ought to comprehend the complexity of the pain in its context.

Older people's self-perception of health (when people evaluate their health status by themselves) was associated with LBP and functional disability. Furthermore, corroborating with these findings, other studies with individuals of various ages showed that LBP's negative beliefs are associated with a higher level of disability $[49,50]$. A study conducted only with older adults without specific health conditions found that the higher the degree of dependence, the greater was the chance that the older person perceived their health as bad [51]. It is theorized that for some individuals with LBP, negative beliefs about pain and/or negative illness information lead to a catastrophize response in which the worst possible outcome is imagined. This leads to fear and avoidance of physical activity, which in turn causes resultant distress, reinforcing the original negative appraisal in a deleterious cycle [52].

The present study had some limitations. Participants were recruited using a convenience sample; only the older people who could be at the places where the evaluations took place participated, which may have contributed to a sample selection bias and compromised the generalization of the results. In addition, the older people who were not able to walk outside were not included and those who used a wheelchair were excluded. Furthermore, in this study, people with more serious LBP and more severe impairments were missed. Characteristics such as age, sex, availability, and interest of the participants may have influenced the recruitment and produced discrepancies in the sample's representativeness; for example, the sample of the present study consisted mostly of women. The proportion of women was higher than that expected from the demographic distribution for the population of older adult women and men in the state of Amazonas. Another limitation was that only the pain intensity scale was used, without using the visual face scale for older adults with lower education levels. On the other hand, we consider our results to be promising for initial public health actions targeting older adults and we encourage more studies because it can be seen as a matter of great importance, as the older population is becoming larger and the costs of treatment are higher than those for preventing the condition. 


\section{Conclusions}

In conclusion, the prevalence of LBP was high (punctual prevalence was $42.4 \%$ and the prevalence for the last 365 days was $93.7 \%$ ). Being female, having fewer years of schooling, a higher BMI, engaging in mostly sedentary behavior, having diseases related to the diet and cardiovascular system, or having impaired emotional levels were associated with LBP, even though they perceived themselves in good health. The findings of this study can be used to coordinate efforts from the government, health professionals, and civil society in order to manage and promote the prevention of LBP by considering the elderly population's needs in the state of Amazonas.

Author Contributions: Conceptualization, I.M.B.d.S. and A.P.M.; methodology, I.M.B.d.S. and A.P.M.; software, J.I.D.F.; validation, I.M.B.d.S., A.P.M. and A.d.C.P.; formal analysis, J.I.D.F.; investigation, I.M.B.d.S., A.P.M. and L.R.M.; resources, A.P.M. and I.M.B.d.S.; writing-original draft preparation, I.M.B.d.S.; writing-review and editing, I.M.B.d.S., A.P.M. and A.d.C.P.; visualization, L.A.V.R.; supervision, I.M.B.d.S. and L.R.M.; project administration, I.M.B.d.S. and A.P.M.; funding acquisition, A.P.M. All authors have read and agreed to the published version of the manuscript.

Funding: The National Council funded this study for Scientific and Technological DevelopmentCNPq (grant number: 408500/2016-6). The funding sources had no role in the study design; in the collection, analysis, or interpretation of data; in the writing of the manuscript; in the decision to submit the manuscript for publication.

Institutional Review Board Statement: The study was conducted according to the guidelines of the Declaration of Helsinki and approved by the Research Ethics Committee of the Faculty of Medicine of the University of São Paulo, São Paulo, Brazil (protocol code: 189/16, date of approval: 8 June 2016).

Informed Consent Statement: Informed consent was obtained from all participants involved in the study.

Data Availability Statement: The data presented in this study are available on request from the corresponding author. The data are not publicly available due to personal participation information.

Acknowledgments: To the physiotherapy undergraduates of the Federal University of Amazonas for their collaboration during data collection. In addition, to all the voluntary participants since without them, this study could not exist.

Conflicts of Interest: The authors declare no conflict of interest.

\section{References}

1. Vos, T.; Allen, C.; Arora, M.; Barber, R.M.; Bhutta, Z.A.; Brown, A.; Carter, A.; Casey, D.C.; Charlson, F.J.; Chen, A.Z.; et al. Global, Regional, and National Incidence, Prevalence, and Years Lived with Disability for 310 Diseases and Injuries, 1990-2015: A Systematic Analysis for the Global Burden of Disease Study 2015. Lancet 2016, 388, 1545-1602. [CrossRef]

2. Dionne, C.E.; Dunn, K.M.; Croft, P.R.; Nachemson, A.L.; Buchbinder, R.; Walker, B.F.; Wyatt, M.; Cassidy, J.D.; Rossignol, M.; Leboeuf-Yde, C.; et al. A Consensus Approach Toward the Standardization of Back Pain Definitions for Use in Prevalence Studies. Spine 2008, 33, 95-103. [CrossRef] [PubMed]

3. Hoy, D.; Bain, C.; Williams, G.; March, L.; Brooks, P.; Blyth, F.; Woolf, A.; Vos, T.; Buchbinder, R. A Systematic Review of the Global Prevalence of Low Back Pain. Arthritis Rheum. 2012, 64, 2028-2037. [CrossRef] [PubMed]

4. Kamper, S.J.; Henschke, N.; Hestbaek, L.; Dunn, K.M.; Williams, C.M. Musculoskeletal Pain in Children and Adolescents. Braz. J. Phys. Ther. 2016, 20, 275-284. [CrossRef] [PubMed]

5. Hartvigsen, J.; Hancock, M.J.; Kongsted, A.; Louw, Q.; Ferreira, M.L.; Genevay, S.; Hoy, D.; Karppinen, J.; Pransky, G.; Sieper, J.; et al. What Low Back Pain is and why we Need to Pay Attention. Lancet 2018, 391, 2356-2367. [CrossRef]

6. Dellaroza, M.S.G.; Furuya, R.K.; Cabrera, M.A.S.; Matsuo, T.; Trelha, C.; Yamada, K.N.; Pacola, L. Caracterização Da Dor Crônica e Métodos Analgésicos Utilizados Por Idosos Da Comunidade. Rev. Assoc. Med. Bras. 2008, 54, 36-41. [CrossRef] [PubMed]

7. Ferreira, G.D.; Silva, M.C.; Rombaldi, A.J.; Wrege, E.D.; Siqueira, F.V.; Hallal, P.C. Prevalência de Dor Nas Costas e Fatores Associados Em Adultos Do Sul Do Brasil: Estudo de Base Populacional. Rev. Bras. Fisioter. 2011, 15, 31-36. [CrossRef]

8. Bressler, H.B.; Keyes, W.J.; Rochon, P.A.; Badley, E. The Prevalence of Low Back Pain in the Elderly: A Systematic Review of the Literature. Spine 1999, 24, 1813. [CrossRef]

9. Weiner, D.K.; Sakamoto, S.; Perera, S.; Breuer, P. Chronic Low Back Pain in Older Adults: Prevalence, Reliability, and Validity of Physical Examination Findings: Physical Examination for Low Back Pain. J. Am. Geriatr. Soc. 2006, 54, 11-20. [CrossRef]

10. De Souza, I.M.B.; Sakaguchi, T.F.; Yuan, S.L.K.; Matsutani, L.A.; do Espírito-Santo, A.D.S.; Pereira, C.A.D.B.; Marques, A.P. Prevalence of Low Back Pain in the Elderly Population: A Systematic Review. Clinics 2019, 74, e789. [CrossRef] 
11. Leopoldino, A.A.O.; Diz, J.B.M.; Martins, V.T.; Henschke, N.; Pereira, L.S.M.; Dias, R.C.; Oliveira, V.C. Prevalence of Low Back Pain in Older Brazilians: A Systematic Review with Meta-Analysis. Rev. Bras. Reumatol. 2016, 56, 258-269. [CrossRef]

12. Alves, L.C.; Leimann, B.C.Q.; Vasconcelos, M.E.L.; Carvalho, M.S.; Vasconcelos, A.G.G.; Fonseca, T.C.O.D.; Lebrão, M.L.; Laurenti, R. A Influência Das Doenças Crônicas Na Capacidade Funcional Dos Idosos Do Município de São Paulo, Brasil. Cad. Saúde Pública 2007, 23, 1924-1930. [CrossRef]

13. Quintino, N.M.; Conti, M.H.S.D.; Palma, R.; Gatti, M.A.N.; Simeão, S.F.A.P.; Vitta, A.D. Prevalence and Factors Associated with Low Back Pain in Elderly Registered in the Family Health Strategy. Fisioter. Mov. 2017, 30, 367-377. [CrossRef]

14. Von Elm, E.; Altman, D.G.; Egger, M.; Pocock, S.J.; Gøtzsche, P.C.; Vandenbroucke, J.P. für die STROBE Initiative Das Strengthening the Reporting of Observational Studies in Epidemiology (STROBE-) Statement: Leitlinien für das Berichten von Beobachtungsstudien. Notfall Rettungsmed 2008, 11, 260-265. [CrossRef]

15. Maher, C.; Underwood, M.; Buchbinder, R. Non-Specific Low Back Pain. Lancet 2017, 389, 736-747. [CrossRef]

16. Hancock, M.J.; Maher, C.G.; Latimer, J.; Spindler, M.F.; McAuley, J.H.; Laslett, M.; Bogduk, N. Systematic Review of Tests to Identify the Disc, SIJ or Facet Joint as the Source of Low Back Pain. Eur. Spine J. 2007, 16, 1539-1550. [CrossRef]

17. Brasil Instituto Brasileiro de Geografia e Estatística Censo Demográfico. 2010. Available online: https://cidades.ibge.gov.br/ brasil/am/manaus/panorama (accessed on 8 June 2020).

18. Berenson, M.; Levine, D.; Szabat, K.A.; Krehbiel, T.C. Estimation and Sample Size Determination for Finite Populations. In Basic Business Statistics: Concepts and Applications; Pearson Higher Education Australia: Melbourne, VIC, Australia, 2012; ISBN 0-13-216838-3.

19. Lipschitz, D.A. Screening for Nutritional Status in the Elderly. Prim Care 1994, 21, 55-67.

20. Craig, C.L.; Marshall, A.L.; Sjöström, M.; Bauman, A.E.; Booth, M.L.; Ainsworth, B.E.; Pratt, M.; Ekelund, U.; Yngve, A.; Sallis, J.F.; et al. International Physical Activity Questionnaire: 12-Country Reliability and Validity. Med. Sci. Sports Exerc. 2003, 35, 1381-1395. [CrossRef]

21. Costa, L.O.P.; Maher, C.G.; Latimer, J.; Ferreira, P.H.; Ferreira, M.L.; Pozzi, G.C.; Freitas, L.M.A. Clinimetric Testing of Three Self-Report Outcome Measures for Low Back Pain Patients in Brazil: Which One is the Best? Spine 2008, 33, 2459-2463. [CrossRef]

22. Nusbaum, L.; Natour, J.; Ferraz, M.B.; Goldenberg, J. Translation, Adaptation and Validation of the Roland-Morris QuestionnaireBrazil Roland-Morris. Braz. J. Med. Biol. Res. 2001, 34, 203-210. [CrossRef] [PubMed]

23. Pereira, J.C.R. Bioestatística Em Outras Palavras; EDUSP Fapesp: São Paulo, Brasil, 2010; ISBN 85-314-1226-9.

24. Munzel, U.; Hothorn, L.A. A Unified Approach to Simultaneous Rank Test Procedures in the Unbalanced One-Way Layout. Biom. J. 2001, 43, 553-569. [CrossRef]

25. Chen, W.; Qian, L.; Shi, J.; Franklin, M. Comparing Performance between Log-Binomial and Robust Poisson Regression Models for Estimating Risk Ratios under Model Misspecification. BMC Med. Res. Methodol. 2018, 18, 63. [CrossRef] [PubMed]

26. Bastos, L.S.; de Oliveira, R.V.C.; de Velasque, L.S. Obtaining Adjusted Prevalence Ratios from Logistic Regression Models in Cross-Sectional Studies. Cad. Saúde Pública 2015, 31, 487-495. [CrossRef] [PubMed]

27. Dellaroza, M.S.G.; Pimenta, C.A.d.M.; Duarte, Y.A.; Lebrão, M.L. Dor Crônica Em Idosos Residentes Em São Paulo, Brasil: Prevalência, Características e Associação Com Capacidade Funcional e Mobilidade (Estudo SABE). Cad. Saúde Pública 2013, 29, 325-334. [CrossRef]

28. Sampaio, L.S.; Reis, L.A.d.; Lessa, R.S.; Torres, G.d.V. Prevalência de Patologias Ortopédicas Em Idosos Atendidos Em Hospital Público No Município de Lajedo Do Tabocal-BA. Enferm Atual 2007, 7, 30-32.

29. Dellaroza, M.S.G.; Pimenta, C.A.d.M.; Matsuo, T. Prevalência e Caracterização Da Dor Crônica Em Idosos Não Institucionalizados. Cad. Saúde Pública 2007, 23, 1151-1160. [CrossRef]

30. Barros, M.B.d.A.; Francisco, P.M.S.B.; Zanchetta, L.M.; César, C.L.G. Tendências Das Desigualdades Sociais e Demográficas Na Prevalência de Doenças Crônicas No Brasil, PNAD: 2003-2008. Ciênc. Saúde Coletiva 2011, 16, 3755-3768. [CrossRef]

31. Hoy, D.; March, L.; Brooks, P.; Blyth, F.; Woolf, A.; Bain, C.; Williams, G.; Smith, E.; Vos, T.; Barendregt, J.; et al. The Global Burden of Low Back Pain: Estimates from the Global Burden of Disease 2010 Study. Ann. Rheum. Dis. 2014, 73, 968-974. [CrossRef]

32. Dionne, C.E.; Dunn, K.M.; Croft, P.R. Does Back Pain Prevalence Really Decrease with Increasing Age? A Systematic Review. Age Ageing 2006, 35, 229-234. [CrossRef]

33. Stewart Williams, J.; Ng, N.; Peltzer, K.; Yawson, A.; Biritwum, R.; Maximova, T.; Wu, F.; Arokiasamy, P.; Kowal, P.; Chatterji, S. Risk Factors and Disability Associated with Low Back Pain in Older Adults in Low- and Middle-Income Countries. Results from the WHO Study on Global AGEing and Adult Health (SAGE). PLoS ONE 2015, 10, e0127880. [CrossRef]

34. Silva, M.C.d.; Fassa, A.G.; Valle, N.C.J. Dor Lombar Crônica Em Uma População Adulta Do Sul Do Brasil: Prevalência e Fatores Associados. Cad. Saúde Pública 2004, 20, 377-385. [CrossRef] [PubMed]

35. Loyola Filho, A.I.d.; Uchoa, E.; Lima-Costa, M.F. Estudo Epidemiológico de Base Populacional Sobre Uso de Medicamentos Entre Idosos Na Região Metropolitana de Belo Horizonte, Minas Gerais, Brasil. Cad. Saúde Pública 2006, 22, 2657-2667. [CrossRef] [PubMed]

36. Murtagh, K.N.; Hubert, H.B. Gender Differences in Physical Disability Among an Elderly Cohort. Am. J. Public Health 2004, 94, 1406-1411. [CrossRef] [PubMed]

37. Bartley, E.J.; Fillingim, R.B. Sex Differences in Pain: A Brief Review of Clinical and Experimental Findings. Br. J. Anaesth. 2013, 111, 52-58. [CrossRef] 
38. Docking, R.E.; Fleming, J.; Brayne, C.; Zhao, J.; Macfarlane, G.J.; Jones, G.T.; on behalf of the Cambridge City over-75s Cohort. Study collaboration Epidemiology of Back Pain in Older Adults: Prevalence and Risk Factors for Back Pain Onset. Rheumatology 2011, 50, 1645-1653. [CrossRef]

39. Waddell, G. Biopsychosocial Analysis of Low Back Pain. Baillière's Clin. Rheumatol. 1992, 6, 523-557. [CrossRef]

40. Shiri, R.; Karppinen, J.; Leino-Arjas, P.; Solovieva, S.; Viikari-Juntura, E. The Association Between Obesity and Low Back Pain: A Meta-Analysis. Am. J. Epidemiol. 2010, 171, 135-154. [CrossRef]

41. Weiner, D.K.; Rudy, T.E.; Kim, Y.-S.; Golla, S. Do Medical Factors Predict Disability in Older Adults with Persistent Low Back Pain? Pain 2004, 112, 214-220. [CrossRef]

42. Corseuil, M.W.; Schneider, I.J.C.; Silva, D.A.S.; Costa, F.F.; Silva, K.S.; Borges, L.J.; d'Orsi, E. Perception of Environmental Obstacles to Commuting Physical Activity in Brazilian Elderly. Prev. Med. 2011, 53, 289-292. [CrossRef]

43. Hallal, P.C.; Andersen, L.B.; Bull, F.C.; Guthold, R.; Haskell, W.; Ekelund, U. Global Physical Activity Levels: Surveillance Progress, Pitfalls, and Prospects. Lancet 2012, 380, 247-257. [CrossRef]

44. Gualano, B.; Tinucci, T. Sedentarismo, Exercício Físico e Doenças Crônicas. Rev. Bras. Educ. Fís. Esporte 2011, 25, 37-43. [CrossRef]

45. Ledoux, É.; Dubois, J.-D.; Descarreaux, M. Physical and Psychosocial Predictors of Functional Trunk Capacity in Older Adults with and without Low Back Pain. J. Manip. Physiol. Ther. 2012, 35, 338-345. [CrossRef]

46. Farias, R.G.; Santos, S.M.A. Dos Influência Dos Determinantes Do Envelhecimento Ativo Entre Idosos Mais Idosos. Texto Contexto Enferm. 2012, 21, 167-176. [CrossRef]

47. Palma, R.; Conti, M.H.S.d.; Quintino, N.M.; Gatti, M.A.N.; Simeão, S.F.A.P.; Vitta, A.d. Functional Capacity and Its Associated Factors in the Elderly with Low Back Pain. Acta Ortop. Bras. 2014, 22, 295-299. [CrossRef]

48. Scherer, M.; Hansen, H.; Gensichen, J.; Mergenthal, K.; Riedel-Heller, S.; Weyerer, S.; Maier, W.; Fuchs, A.; Bickel, H.; Schön, G.; et al. Association between Multimorbidity Patterns and Chronic Pain in Elderly Primary Care Patients: A Cross-Sectional Observational Study. BMC Fam. Pract. 2016, 17, 68. [CrossRef]

49. Elfering, A.; Mannion, A.F.; Jacobshagen, N.; Tamcan, O.; Müller, U. Beliefs about Back Pain Predict the Recovery Rate over 52 Consecutive Weeks. Scand. J. Work Environ. Health 2009, 35, 437-445. [CrossRef]

50. Smith, A.J.; O'Sullivan, P.B.; Beales, D.; Straker, L. Back Pain Beliefs are Related to the Impact of Low Back Pain in 17-Year-Olds. Phys. Ther. 2012, 92, 1258-1267. [CrossRef]

51. Alves, L.C.; Rodrigues, R.N. Determinantes Da Autopercepção de Saúde Entre Idosos Do Município de São Paulo, Brasil. Rev. Panam. Salud Publica 2005, 17. [CrossRef] [PubMed]

52. Linton, S.J.; Shaw, W.S. Impact of Psychological Factors in the Experience of Pain. Phys. Ther. 2011, 91, 700-711. [CrossRef] [PubMed] 